\title{
Evaluation of Vitamin D levels of patients with Type 2 Diabetes Mellitus taking oral antidiabetic drugs
}

\author{
Harun Dugeroglu ${ }^{1(\underline{D})}$ \\ ${ }^{1}$ Department of Internal Medicine, Faculty of Medicine, Ordu University, Ordu, Turkey
}

Copyright@ Author(s) - Available online at https://dergipark.org.tr/en/pub/mbsjohs Content of this journal is licensed under a Creative Commons Attribution-NonCommercial 4.0 International License,

Received: 05 May 2021, Accepted: 16 June 2021, Published online: 31 August 2021

(C) Ordu University Institute of Health Sciences, Turkey, 2021

\begin{abstract}
Objective: The aim of this study was to evaluate the vitamin D levels of type 2 diabetes Mellitus (T2DM) patients taking oral antidiabetic drugs.

Methods: The data of 276 T2DM patients who applied to the internal medicine outpatient clinic of our hospital between January-2020 and March-2021, and the control group consisting of normoglycemic individuals in the same age group, as well as the data of 130 patients, were retrospectively reviewed from archive records. Patients with serum 25-hydroxyvitamin D (25(OH)D) level below $30 \mathrm{ng} / \mathrm{mL}$ were accepted as vitamin D deficiency and insufficiency, and patients with serum $25(\mathrm{OH}) \mathrm{D}$ levels above $30 \mathrm{ng} / \mathrm{mL}$ were accepted as normal vitamin D adequacy. The data of T2DM patients taking oral antidiabetic drugs and the data of normoglycemic control group patients were statistically compared.

Results: $60.8 \%(\mathrm{n}=168)$ of T2DM patients taking 276 oral antidiabetic drugs included in the study were female and $39.2 \%(\mathrm{n}=108)$ were male. The mean age of the patients was $52.5 \pm 4.2$ years. The mean serum $25(\mathrm{OH}) \mathrm{D}$ level of the T2DM group patients taking oral antidiabetic drugs was $9.6 \pm 4.3 \mathrm{ng} / \mathrm{mL}$. Of the 130 patients taken as the normoglycemic control group, 65.3\% $(n=85)$ were female and $34.7 \%(n=45)$ were male. The mean age of these patients was 53.6 \pm 4.4 years. Mean serum 25(OH)D level of the control group was $16.1 \pm 4.6 \mathrm{ng} / \mathrm{mL}$. When the 25(OH)D levels, HOMA-IR, fasting blood glucose, HbA1c and BMI ratios of the T2DM group patients taking oral antidiabetic drugs were compared statistically compared to the normoglycemic control group patients, significant differences were found between the groups (respectively; $\mathrm{p}<0.01 ; \mathrm{p}<0.01 ; \mathrm{p}<0.01 ; \mathrm{p}<0.01 ; \mathrm{p}<0.01)$.

Conclusion: The fact that vitamin D levels were found to be significantly lower in T2DM patients taking oral antidiabetic drugs compared to the normoglycemic control group suggests that vitamin D deficiency has an important place in the formation of T2DM. We think that early vitamin D replacement therapy in these patients may be a preventive factor in the formation of T2DM.
\end{abstract}

Key words: Vitamin D, Oral antidiabetic drugs, Type 2 diabetes mellitus

Suggested Citation: Dugeroglu H. Evaluation of Vitamin D Levels of Patients With Type 2 Diabetes Mellitus Taking Oral Antidiabetic Drugs..Mid Blac Sea Journal of Health Sci, 2021; 7(2):164-167

Address for correspondence/reprints:

Harun Dugeroglu

Telephone number: +90 5304641575

E-mail: Harun.dugeroglu@hotmail.com 


\section{Introduction}

Diabetes mellitus (DM) is the most common endocrinological disease. Today, it is considered an epidemic disease in many developed and developing countries and ranks fourth among the top five causes of death in most developed countries. DM is a chronic, hyperglycemic, metabolic disorder that causes disorders in carbohydrate, protein and fat metabolism as a result of a series of pathological events caused by genetic and immune structure, the absolute or relative insufficiency or ineffectiveness of the insulin hormone secreted from pancreatic beta cells, cataking complications in almost all systems. is a disease (1).

Type $2 \mathrm{DM}$ is often characterized by a strong genetic load. Family history is present in almost all of them. Three important factors play a role in its pathogenesis: Disruption of pancreatic beta cell insulin secretion, insulin resistance and increased liver glucose production. It is mostly seen in elderly people, sedentary people and obese people. However, although it is known to be seen in non-obese patients, this becomes important in etiological classification. Accordingly, while insulin resistance is more important in obese type $2 \mathrm{DM}$, insulin secretion disorder is in the first place in non-obese ones (2).

Endogenous vitamin D status is determined by the serum 25-hydroxy vitamin D $(25(\mathrm{OH}) \mathrm{D})$ level. $25(\mathrm{OH}) \mathrm{D}$ level is the best indicator for defining vitamin D deficiency and insufficiency. There is no clear consensus regarding vitamin D deficiency, insufficiency and optimal 25(OH)D levels. Vitamin $\mathrm{D}$ deficiency is defined as the lowest serum $25(\mathrm{OH}) \mathrm{D}$ level $(20 \mathrm{ng} / \mathrm{ml})$ that prevents secondary hyperparathyroidism, increased bone formationdestruction and bone mineral loss. Serum $25(\mathrm{OH}) \mathrm{D}$ level below $12 \mathrm{ng} / \mathrm{ml}$ was associated with a decrease in muscle strength. Serum $25(\mathrm{OH}) \mathrm{D}$ levels are recommended to be above $30 \mathrm{ng} / \mathrm{ml}$ for maximum calcium absorption and optimal health (3).

Although DM, which is among the causes of secondary osteoporosis, is a heterogeneous group of disorders with different causes, it is characterized by hyperglycemia, absolute or relative insulin insufficiency or insulin resistance, and a tendency to develop some long-term complications (4).

Vitamin D can affect insulin secretion and fat breakdown. The genetic diversity of the vitamin D receptor (VDR) is widespread, and its relationship with bone mineral density and type $2 \mathrm{DM}$ has been demonstrated in many studies. Although the relation of VDR gene diversity with high rate of obesity and early onset type $2 \mathrm{DM}$ has been shown, the pathophysiological mechanism has not been explained (5).

Vitamin $D$ reduces insulin resistance in surrounding tissues, thereby reducing excess insulin secretion that occurs in response to the increase in blood sugar due to insulin resistance and increases insulin sensitivity. It has been shown that vitamin D deficiency is a risk factor for metabolic syndrome and type $2 \mathrm{DM}$, and that vitamin $\mathrm{D}$ deficiency is associated with insulin resistance and-cell dysfunction (6,7).

The aim of this study was to evaluate vitamin D levels in type $2 \mathrm{DM}$ patients taking oral antidiabetic drugs. Thus, we think that adding vitamin D prophylactically to type $2 \mathrm{DM}$ patients will be beneficial in the patient's clinic and in preventing complications that may develop in the patient.

\section{Methods}

The data of 276 patients with Type 2 DM who applied to the internal medicine outpatient clinic of our hospital between January-2020 and March-2021, and the control group consisting of normoglycemic individuals in the same age group, were retrospectively reviewed from archive records. The data of the patients (age, gender, serum 25(OH)D level, biochemical parameters, parathyroid hormone) were retrospectively reviewed from file records. Serum 25(OH)D levels were studied in Abbott Architect i2000-SR autoanalyzer in our hospital. Patients with serum 25(OH)D level below $30 \mathrm{ng} / \mathrm{ml}$ were accepted as vitamin D deficiency and insufficiency, and patients with serum $25(\mathrm{OH}) \mathrm{D}$ levels above $30 \mathrm{ng} / \mathrm{ml}$ were accepted as normal vitamin $\mathrm{D}$ adequacy. The data of T2DM patients taking oral antidiabetic drugs and the data of normoglycemic control group patients were statistically compared.

\section{Exclusion Criteria}

Patients receiving vitamin D and immunosuppressive drug therapy, patients with bone metabolism disease, cancer patients, breastfeeding and pregnant patients, patients diagnosed with osteoporosis and osteomalacia, patients with primary hyperparathyroidism, patients with chronic renal failure, patients taking alcohol and smoking and archive records are insufficient. and missing patients were excluded from the study.

\section{Statistical Analysis}

All data were uploaded to SPSS 22.0 program. In the evaluation of the data, number(n), percentage (\%), mean and standard deviation were used for 
descriptive statistics. Data were analyzed by Kolmogorov-Smirnow test. Student-t test was used to compare the groups. Pearson and Spearman tests were used for correlation analysis. $\mathrm{P}$ value less than 0.05 was considered significant.

\section{Results}

$60.8 \%$ ( $\mathrm{n}=168$ ) of T2DM patients taking 276 oral antidiabetic drugs included in the study were female and $39.2 \%(n=108)$ were male. The mean age of the patients was $52.5 \pm 4.2$ years (men $51.7 \pm 11.4$ years, women $53.5 \pm 12.1$ years). The mean serum $25(\mathrm{OH}) \mathrm{D}$ level of the T2DM group patients taking oral antidiabetic drugs was $9.6 \pm 4.3 \mathrm{ng} / \mathrm{ml}$. Of the 130 patients taken as the normoglycemic control group, $65.3 \%(n=85)$ were female and $34.7 \%(n=45)$ were male. The mean age of these patients was $53.6 \pm 4.4$ years (men $53.5 \pm 10.4$ years, women $52.6 \pm 11.7$ years). Mean serum 25(OH)D level of the normoglycemic control group was $16.1 \pm 4.6 \mathrm{ng} / \mathrm{ml}$.

When the 25(OH)D levels, HOMA-IR, fasting blood glucose, HbA1c and BMI ratios of the T2DM group patients taking oral antidiabetic drugs were compared statistically compared to the normoglycemic control group patients, significant differences were found between the groups (respectively; $\mathrm{p}<0.01 ; \mathrm{p}<0.01 ; \mathrm{p}<0.01 ; \mathrm{p}<0.01 ; \mathrm{p}$ $<0.01)$ (Table 1).

Table 1. Demographic and laboratory findings of the groups.

\begin{tabular}{|c|c|c|c|}
\hline \multirow[t]{2}{*}{ PARAMETERS } & $\begin{array}{c}\text { T2DM } \\
(n=276)\end{array}$ & $\begin{array}{l}\text { Control } \\
\text { group } \\
(\mathrm{n}=130)\end{array}$ & \multirow[t]{2}{*}{ P value } \\
\hline & Mean \pm SD & Mean \pm SD & \\
\hline Age (year) & $52.5 \pm 4.2$ & $53.6 \pm 4.4$ & 0.862 \\
\hline Gender (F/M) & $168 / 108$ & $85 / 45$ & 0.142 \\
\hline $25(\mathrm{OH}) D(\mathrm{ng} / \mathrm{ml})$ & $9.6 \pm 4.3$ & $16.1 \pm 4.6$ & $<0.01$ \\
\hline $\mathrm{Ca}(\mathrm{mg} / \mathrm{dl})$ & $8.2 \pm 0.4$ & $8.9 \pm 0.6$ & 0.178 \\
\hline$P$ (mg/dl) & $3.2 \pm 0.2$ & $3.3 \pm 0.5$ & 0.243 \\
\hline PTH (pg/ml) & $55.3 \pm 24.6$ & $53.2 \pm 23.5$ & 0.451 \\
\hline Albumin (g/dl) & $4.6 \pm 0.3$ & $4.5 \pm 0.2$ & 0.315 \\
\hline HOMA-IR & $5.3 \pm 3.5$ & $1.9 \pm 0.8$ & $<0.01$ \\
\hline FBG (mg/dl) & $186.4 \pm 72.5$ & $88.4 \pm 6.7$ & $<0.01$ \\
\hline HbA1c (\%) & $8.7 \pm 2.3$ & $5.6 \pm 0.8$ & $<0.01$ \\
\hline BMI $\left(\mathrm{kg} / \mathrm{m}^{2}\right)$ & $30.6 \pm 3.8$ & $27.3 \pm 4.2$ & $<0.01$ \\
\hline
\end{tabular}

BMI: Body mass index, FBG: Fasting blood glucose, HbA1c: Hemoglobin resistance, Ca: Calcium, P: Phosphorous, PTH: Parathyroid hormone, 25( deviation, M: Male, F: Female, n: number.

T2DM: Type 2 Diabetes Mellitus.

\section{Discussion}

It has been reported that the incidence of diabetes has been increasing rapidly in dangerous proportions in recent years. According to WHO, it is estimated that there are more than 180 million diabetic patients in the world and this figure is expected to increase more than double in 2030 (8). In our study, when vitamin D levels of the normoglycemic control patient group and T2DM patients taking oral antidiabetic drugs were compared, vitamin D levels were found to be significantly lower in the T2DM patient group.

Studies have suggested that vitamin D may have an effect on insulin resistance by regulating both calcium metabolism and insulin receptor gene expression (9).

Vitamin D has an important role both in the pathogenesis of bone diseases and calcium homeostasis and in the development of various chronic diseases. It has been suggested that vitamin D deficiency is a risk factor in the development of DM. Knekt et al. (10) supports the hypothesis that high vitamin D levels are protective against T2DM.

Shankar et al. (11) found a positive relationship between low vitamin D levels and diabetes. In this study, it is emphasized that vitamin D treatment is effective in protecting against diabetes and the importance of vitamin $\mathrm{D}$ in diabetes.

Another study Modi et al. (12). In this study, they found that the vitamin $\mathrm{D}$ levels of diabetic patients were statistically lower than the control group. Targher et al. (13) found in their study that DM patients with low vitamin D levels had high $\mathrm{HbA1c}$ levels. They attributed this to the healing effect of vitamin $\mathrm{D}$ on beta cell functions. In this study, we found that as the $\mathrm{HbA} 1 \mathrm{c}$ level increases in diabetic patients, the vitamin D level decreases.

However, Giorelli et al. (14) found low levels of vitamin $\mathrm{D}$ in both the diabetic group and the control group without a statistically significant difference between them. These different results may be due to seasonal difference, skin pigmentation difference and ethnic group difference.

Chiu et al. (6) found that there was a positive correlation between $25(\mathrm{OH}) \mathrm{D}$ levels and insulin sensitivity and the negative effects of vitamin D deficiency on beta cell function in 126 individuals without diabetes, with glucose intolerance, by adjusting parameters such as age, gender, and alcohol. It has been shown to be. As a result, individuals with vitamin D deficiency seemed to be at risk in terms of insulin resistance and diabetes development.

In a similar study, Baynes et al. (15) found a statistically significant difference between increased fasting plasma glucose and decreased vitamin D levels in their study, which included 126 people without DM disease.

However, Davidson et al. (16), in the study they conducted with diabetic patients with low vitamin D levels, showed that keeping vitamin D levels normal 
with vitamin D supplements for 1 year had no effect on insulin secretion, insulin sensitivity and diabetes development.

\section{Conclusion}

The relationship between vitamin D levels and the development of diabetes has been demonstrated in many studies. Vitamin D deficiency is thought to trigger insulin resistance and is one of the reasons leading to T2DM. In our study, the fact that vitamin $\mathrm{D}$ levels were found to be significantly lower in T2DM patients taking oral antidiabetic drugs compared to the normoglycemic control group suggests that vitamin D deficiency has an important place in the formation of T2DM. We think that early vitamin D replacement therapy in these patients may be a preventive factor in the formation of T2DM.

Ethics Committee Approval: Ethics committee approval was obtained from Clinical Research and Ethics Committee (Report no: 2021/114).

Peer-review: Externally peer-reviewed.

Author Contributions:

Concept, Design, Literature search, Data Collection and Processing, Analysis or Interpretation, Writing H.D.

Conflict of Interest: No conflict of interest was declared by the authors.

Financial Disclosure: The authors declared that this study hasn't received no financial support.

\section{References}

1. Tabak AG, Herder C, Rathmann W, Brunner EJ, Kivimaki M. Prediabetes: a high risk state for diabetes development. The Lancet 2012;379(9833):2279-90.

2. Yenigun M. All Aspects of Diabetes Mellitus. Second Edition. İstanbul: Nobel Medical Bookstore; 2001. p:51-243.

3. Baflaran S, Guzel R, Benlidayı IC, Uysal F. Osteoporozda vitamin D duzeyinin yasam kalitesi uzerine etkisi. Osteoporoz Dunyasından 2006;12(2):35-8.

4. Taylor GW, Burt BA, Becker MP, Genco RJ, Shlossman M. Glycemic control and alveolar bone loss progression in type 2 diabetes. Ann Periodontol 1998;3:30-9.

5. Ye WZ, Reis AF, Dubois-Laforgue D, BellanneChantelot C, Timsit J, Velho G. Vitamin D receptor gene polymorphisms are associated with obesity in type 2 diabetic subjects with early age of onset. Eur J Endocrinol 2001;145:181-6.
6. Chiu KC, Chu A, Go VL, Saad MF. Hypovitaminosis D is associated with insulin resistance and $\beta$ cell dysfunction. Am J Clin Nutr 2004;79:820-5.

7. Boucher BJ, Mannan N, Noonan K, Hales CN, Evans SJ. Glucose intolerance and impairment of insulin secretion in relation to vitamin D deficiency in east London Asians. Diabetologia 1995;380:1239-45.

8. Teegarden D, Donkin SS. Vitamin D: emerging new roles in insulin sensitivity. Nutrition Research Reviews 2009;22;82-92.

9. Ozfirat Z. Chowdhury TA. Vitamin D deficiency and type 2 diabetes. Postgrad Med J 2010;86:1825.

10. Knekt P, Laaksonen M, Mattila C, et al. Serum Vitamin D and Subsequent Occurrence of Type 2 Diabetes. Epidemiology 2008;19:666-71.

11. Shankar A, Sabanayagam C, Kalıdındı S. Serum 25-Hydroxyvitamin D Levels and Prediabetes Among Subjects Free of Diabetes. Diabetes Care 2011;34:1114-19.

12.Modi KD, Ahmed MI, Chandwani R, Hari Kumar KVS. Prevalance of vitamin D deficiency across the spectrum of glucoseintolerance. Journal of Diabetes \& Metabolic Disorder 2015;14:54.

13. Targher G, Bertolini L, Padovani R. Serum 25hydroxyvitamin D3 concentrations and carotid artery intima-media thickness among type 2 diabetic patients. Clin Endocrinol 2006;65:59397.

14.Giorelli GDV, Matos LND, Saado A, Soibelman VL, Dias CD. No association between 25hydroxyvitamin $\mathrm{D}$ levels and prediabetes in Brazilian patients. A cross- sectional study. Sao Paulo Med J 2015;133(2):73-7.

15.Baynes KC, Boucher BJ, Feskens EJ, Kromhout D.Vitamin D, glucose tolerance and insulinaemia in elderly men. Diabetologia 1997;40:344-47.

16.Davidson MB, Duran P, Lee ML, Friedman TC. High Dose Vitamin D Supplementation in People with Prediabetes and Hypovitaminosis D. Diabetes Care 2013;36:260-6. 